\title{
Sefarad ¿la «patria» de los sefardíes?*
}

\author{
Pilar Romeu Ferré
}

Barcelona

\begin{abstract}
A lo largo del siglo XX y en lo que va del XXI se han publicado en diferentes países centenares de libros de memorias, novelas autobiográficas y testimonios de historia oral de judíos sefardíes. Tema recurrente en su discurso es la reflexión acerca de cuál sea su «patria». En este estudio analizamos qué nos dicen al respecto y cuál consideran ellos su «patria».

PAlabras Clave: Sefarad; judíos sefardíes; Imperio otomano; construcción de la memoria; transnacionalismo; autobiografía; occidentalización; literatura sefardí.

Sefarad: The Homeland of the Sephardic Jews?.- During the $20^{\text {th }}$ Century and the early years of the $21^{\text {st }}$, various studies have been published in different countries, concerning the question of a definitive homeland for the Sephardic Jews. Autobiographical reminiscenses and novels and oral testimonies have all been concerned with this topic. In the present study the author analyzes the information provided by these writings and the countries Sephardic Jews consider to be their Homeland.
\end{abstract}

KeYwords: Sepharad; Sephardic Jews; Ottoman Empire; Construction of Memoirs; Transnationalism; Autobiography; Westernization; Sephardic Literature.

Como es bien sabido, los judíos sefardíes son los descendientes de los judíos expulsados de la Península Ibérica en el siglo XV y los que se han asimilado socio-culturalmente a ellos conservando los rasgos culturales hispánicos hasta el día de hoy —especialmente la lengua, el judeoespañol—. Se llaman a sí mismos sefardíes porque provenían de Sefarad, nombre hebreo con que designaban

* Este estudio se ha realizado en el marco del proyecto de investigación FFI 2009-07026, «Los sefardíes ante sí mismos y en sus relaciones con España» (dir. Dra. Paloma Díaz-Mas).

** tirocinio@ tirocinio.com 
su tierra de origen ${ }^{1}$. Entre ellos distinguimos tres grandes grupos: los sefardies orientales, asentados en su mayoría en el Imperio otomano; los sefardíes del Norte de África; y los sefardies occidentales, cuyos círculos de influencia son europeos (Países Bajos, Hamburgo, Venecia, Liorna), pero cuya formación y desarrollo habrá de esperar casi un siglo, hasta finales del siglo XVI y principios del XVII.

Más de un siglo ha transcurrido desde que en 1905 Ángel Pulido publicara su libro Españoles sin Patria y la Raza Sefardí (Madrid: Establecimiento Tipográfico de E. Teodoro, 1905). El título de ese libro es el punto de partida de este estudio: ¿Existe una Patria para los sefardíes? Y si existe, ¿cuál es?

Las reflexiones que siguen se basan en el análisis de lo que los propios sefardíes originarios de los territorios del antiguo Imperio otomano dicen al respecto en sus memorias y que nos ilustran acerca de cómo se construye su identidad en la nueva diáspora, en la llamada Segunda Diáspora sefardí ${ }^{2}$.

Los testimonios han sido escritos en diversas lenguas - la mayoría en inglés o francés, pero también en alemán, búlgaro, hebreo, macedonio, serbo-croata, castellano y judeoespañol- por personas de diversa extracción social y procedencia, con profesiones muy variadas (artistas, comerciantes, economistas, escritores, físicos, ingenieros, médicos, policías, políticos, profesores, sastres y

\footnotetext{
${ }^{1}$ Nos referimos a Sefarad como sinónimo de Península Ibérica y al gentilicio sefardíes para denominar a los judíos originarios de Sefarad. Si bien el sentido actual de España no es aplicable a la historia del judaísmo medieval en la Península y los estudiosos creen incorrecto designar como sefardíes a los judíos que vivían allí durante la época medieval, ese es el apelativo con el que se identificaban fuera de la península. En obras sefardíes de los siglos XVI y XVII se usa ya el término España para referirse a la Península. Valgan tres ejemplos: 1) En la Biblia de Ferrara (1553): «Y captiverio del fonsado este á hijos de Israel que mercaderes hasta Francia y captiverio de Yerusalaim que en España [Ab 20]»; 2) En la obra Fuente clara (Salónica, 1595): «Profetiza más el profeta: Cativerio del fonsado este a fijos de Yisrael, que mercador fasta França, y catiberio de Yeruxaláyim que en España, eredarán a cibdades del darom [Ab 20]. Esta profezía se puede entender por lo que vemos en nuestros días que muchos del cativerio de Yeruxaláyim que en España, por fuiren del fuerte cativerio que en España, como mercaderes se passan fasta França» (Romeu 2007: 112); 3) Iacob CAnsino, en su edición de los Extremos y Grandezas de Constantinopla de Moisés Almosnino (Madrid, 1638), dice: «donde curan los enfermos pobres que se vienen alli à recoger, y curar (que es lo que los Españoles llaman Hospital) y ellos Timarhana (pág. 151)», aunque en el único manuscrito que se conserva de esta obra, y que es una copia hecha antes de 1666, dice: «onde están todos los enfermos, que es lo que nosotros llamamos hospital y ellos llaman timar haná» (Romeu 1998: 185).

${ }^{2}$ Para este estudio no hemos tenido en cuenta las narraciones de los sefardíes occidentales ni del Norte de África, como tampoco las de los sefardíes que viven en Israel y las de los orientales que tienen como tema preferente el Holocausto. Tampoco hemos tenido en cuenta, salvo casos puntuales, las que se han publicado en periódicos y revistas, o las que permanecen inéditas.
} 
un largo etcétera de profesiones), buena parte de los cuales salió —o nació yafuera del lugar de origen de su familia. Aunque entre ellos hay algunos tan notorios como el premio nobel Elías Canetti (nacido en Bulgaria) o Albert Cohen, la mayoría de los autores no son escritores profesionales, sino gente corriente que ha sentido la necesidad de contar sus vivencias como parte de la construcción de su propia identidad. Son narraciones autobiográficas (más o menos ficcionalizadas $^{3}$ ) escritas sobre todo por personas nacidas entre principios del siglo XX y los años 40, es decir, los últimos sefardíes que alcanzaron a conocer la vida de las comunidades tradicionales sefardíes del viejo Imperio otomano, bien directamente en su niñez, bien a través de la memoria y la tradición oral familiar de sus padres y abuelos. La reivindicación de su pasado y la lucha contra la desaparición se erigen en la finalidad de muchas de ellas. Son y se sienten testigos privilegiados de una época ya obsoleta.

Cronológicamente cubren tres etapas: 1) Oriental ${ }^{4}$ (hasta la Primera Guerra Mundial); 2) De emigración y reasentamiento en los nuevos países — hasta los años 20-30 del siglo pasado_-; y 3) De afirmación en la Segunda Diáspora. La primera etapa corresponde con las últimas décadas que vivieron como grupo homogéneo en el Imperio otomano las comunidades sefardíes orientales instaladas allí tras la expulsión de España de 1492. La segunda se inicia con las revoluciones sociales, políticas y económicas de finales del siglo XIX y principios del XX que se produjeron a nivel mundial y que provocaron el éxodo masivo de sefardíes hacia otros centros económicos. Quienes permanecieron en sus lugares de origen, por ejemplo en Turquía tras la proclamación de la República el 29 de octubre de 1923, vivieron también cambios fundamentales en las estructuras políticas sociales y económicas del propio país que afectaron a su forma de vida, y que son comparables a los que vivieron quienes emigraron. La tercera etapa ve el resurgir de nuevas comunidades o grupúsculos sefardíes en la nueva diáspora ${ }^{5}$.

Desde el punto de vista literario, para reconstruir su memoria personal, los sefardíes han escrito obras que podrían encuadrarse en distintos géneros literarios: biografías, autobiografías, colecciones epistolares, novelas, cuentos,

${ }^{3}$ En ese sentido, podríamos hablar de «ficciones autobiográficas» en el sentido que ya destacó FELDMAN (2003-2004: 114-120) para los testimonios israelíes.

${ }^{4}$ Aunque propiamente los países balcánicos no son orientales, formaron parte del Imperio otomano hasta el siglo XIX. Algunos con intermitencias, como Bosnia, que entre 1718-1739 y 1908-1918 formó parte del Imperio austro-húngaro.

${ }^{5}$ Entre los estudios históricos que pueden ayudar a comprender el alcance de esos acontecimientos y el impacto en la sociedad sefardí oriental están los de BENBASSA \& RodRIGUE (2004) y Méchoulan (1993). 
poesía, relatos y narraciones biográficas e historias de vida. El sentimiento identitario es necesario para escribir un relato personal. Como veremos, entre los sefardíes esta cuestión no está resuelta, como tampoco se ha resuelto en la literatura judía en general. Las razones son múltiples (históricas, sociológicas y literarias), como ya notó Varol (2003-2004: 234), y no vienen aquí al caso, pero apuntemos a la progresiva desaparición de las comunidades de origen, a la creación del Estado de Israel en 1948 y al Holocausto como tres factores preponderantes. Entre los sefardíes en general, tanto como en la literatura judía e israelí, no abunda la literatura escrita de tipo biográfico, pero sí en la tradición oral. Por eso es habitual encontrar materia autobiográfica en géneros tan dispares como la poesía, relatos ejemplares y cantos tradicionales, y tenemos obras tan difícilmente clasificables entre la autobiografía, el testimonio y la poesía como la carta bilingüe que escribió Marcel Cohen a su amigo el pintor Antonio Saura (Cohen 1997).

No es sino a partir de los años 60-70 del siglo pasado que toman cuerpo las narraciones autobiográficas, y generalmente lo hacen en forma de crónica familiar, al estilo saga (Abinun, Alhadeff, Perera) o se organizan en torno a acontecimientos colectivos de importancia nacional que funcionan como ejes en los que se enclavan las experiencias individuales de los protagonistas (Haskell, Kolonomos, Maimon). Ahí late con fuerza el «yo colectivo» más que el «yo individualizado» por el deseo de los autores de forjar un continuum entre el pasado y el presente que pueda definir una nueva identidad (Feldman 2003-2004: 124). El culto al individualismo no ha echado raíces entre los sefardíes hasta el último decenio, especialmente en lo que va de siglo, cuando se han comenzado a publicar con empuje testimonios particulares (Mordoh, Mostrel, Serotte), aunque muchos se siguen organizando como una saga familiar (Papo, Shaltiel-Gracian).

\section{LA IMAGEN DE ESPAÑA: ENCUENTROS Y DESENCUENTROS}

Estudiosos e investigadores coinciden en señalar que el desencuentro entre España y los sefardíes arranca de 1492, cuando se inició la Primera Diáspora sefardí. Con la entrada en vigor el 1 de mayo de 1492 del Decreto de Expulsión firmado en Granada el 31 de marzo por los reyes de Castilla y Aragón (cuyo texto había sido preparado por el Inquisidor general Tomás de Torquemada ${ }^{6}$ ),

${ }^{6}$ El Decreto se divulgó en varios textos, siendo el más duro el de Aragón, en el que menciona la función determinante de Torquemada en su redacción y la práctica de la «usura» como uno de los factores de expulsión (AlCALÁ 1992: 125-133). 
se inició el proceso de separación física entre los dos pueblos cuando expiró el plazo el 31 de julio del mismo año. Sus lazos no serían a partir de entonces sino esporádicos hasta prácticamente la segunda mitad del siglo XIX. Con todo, se deshicieron mucho antes entre los españoles que entre los sefardíes. Durante los dos primeros siglos en la diáspora, los contactos de los sefardíes con España no se interrumpieron del todo, por varios motivos: 1) Los conversos que vivían en la Península y que habían sido educados como cristianos, fueron llegando a las comunidades orientales hasta bien entrado el siglo XVIII, la mayoría para recobrar de nuevo su judaísmo ${ }^{7}$; 2) Los comerciantes judíos realizaban sus operaciones por todo el Mediterráneo; 3) Las familias mantenían lazos por medio de alianzas matrimoniales estratégicas; y 4) Había contactos esporádicos entre representantes judíos de los diversos gobiernos y viajeros que narraban sus peripecias (Benardete 1965: 98-105). Por tanto, los sefardíes - a un cierto nivelestarían al corriente de lo que sucedía en España. En cambio, ésta les ignoró hasta finales del siglo XIX. Sin embargo, cuando se menciona el tema Patria, todos vuelven mecánicamente la mirada a la Sefarad ancestral.

La historia del desencuentro entre España y sus judíos la explica Bensignor con la metáfora del amado ausente del Cantar de los Cantares, una de cuyas lecturas interpretativas involucra al amante (Dios) en su amor por la amada (la progenie de Israel), y que la autora explica así: el novio (el pueblo judío sefardí), repudiado por la novia (Sefarad), parte cabizbajo hacia el exilio: Cercano Oriente, Norte de África, Balcanes, Egeo...

Pero, a ti te sedujo el mar y el cielo de Izmir. Y volviste a nacer y allí nacieron tus hijos [...]. Fue tu segundo amor, pero jamás olvidaste el primero y seguiste hablando su lengua y perdonaste a la que te hirió (Bensignor 2004: 59-60) ${ }^{8}$.

La auténtica conmoción tuvo lugar en España a principios del siglo XX con el descubrimiento de los sefardíes orientales por el Dr. Ángel Pulido (Díaz-Mas 2006: 217-232), pero las relaciones epistolares que mantuvieron intelectuales

${ }^{7}$ Es el caso, por ejemplo, del autor de la obra Fuente clara, publicada en Salónica hacia 1595, cuya edición crítica moderna se ha subtitulado Un converso sefardí a la defensa del judaísmo y a la búsqueda de su propia fe (Romeu 2007). El autor, anónimo, se educó en escuelas cristianas y era, sin duda, de origen sefardí (Romeu 2006: 29-54).

${ }^{8}$ Del mismo modo que no se han utilizado fragmentos de todas las memorias sefardíes que conocemos, los que se han extractado lo han sido siempre en la lengua del libro que hemos utilizado. 
de elite de ambos bandos ${ }^{9}$, nunca involucraron ni al pueblo menudo sefardí ni al español.

Por entonces, y desde hacía unas décadas, los sefardíes se veían inmersos en un fuerte proceso de occidentalización debido, en parte, al progresivo deterioro del Imperio otomano y la influencia educativa francesa e italiana de las escuelas de la Alliance Israélite Universelle y Dante Alighieri. Los sefardíes entraron en el mundo moderno de la mano de otras culturas (francesa, italiana) y de otros pueblos (Grecia, Turquía, los países balcánicos). España no contribuyó al proceso de modernización de los judíos sefardíes pese a la atención de los intelectuales de elite en los años críticos del cambio de siglo.

Es falso lugar común forjado durante la época de la campaña de Pulido, que ha perdurado hasta nuestros días, la fidelidad y el arraigo que los sefardíes mostraron siempre hacia España después de 1492, una de cuyas «pruebas» evidentes sería la «conservación» de su lengua. Hassán lo ha desmentido repetidamente. Creo, con Hassán (1995: 120), que «los sefardíes conservaron como seña de identidad [...] su lengua hispana [como sus costumbres y su religión], no por fidelidad a sus raíces o por amor a la madrastra patria España [...], sino por fidelidad a sí mismos o por amor "propio"». Sin embargo, tanto la lengua que siguen hablando como la imagen mítica que tienen de Sefarad, constituyen dos pilares de la identidad sefardí de hoy, como pueden serlo la religión o los usos culinarios. Por ello, no pueden englobarse entre los sefardíes - y sus memorias - a judíos de otras procedencias ${ }^{10}$.

En el otro extremo, del examen de la literatura sefardí del período de la Haskalá (s. XVIII-XIX) parece desprenderse que «lo único que de forma casi exclusiva ha interesado a los sefardíes... [ha] sido la Inquisición, los conversos y el modo de la expulsión. [...] España queda pues tipificada para los sefardíes en la saña inquisitorial y con ello han olvidado los períodos de convivencia pacífica, que sí los hubo, y lo que es más grave, tampoco recuerdan a los grandes hombres de letras y ciencias que en los reinos hispanos árabes y cristianos vivieron en condiciones tales que les permitieron llegar a ser preclaros ejemplos para el mundo judío y para la cultura del mundo de Occidente. Y si por acaso recuerdan tales nombres, lo hacen desgajándolos de la sociedad en la que alentaron, como si hubieran nacido y vivido en una especie de limbo fuera del tiempo y del espacio» (Romero 1997: 325-326).

\footnotetext{
${ }^{9}$ Recogidas por el propio Pulido en varios lugares de su libro Españoles sin Patria y la Raza Sefardí (Madrid, 1905).

${ }^{10}$ Véase DíAz-Mas 2006: 28-30.
} 
Más adelante en el tiempo, la imagen contradictoria que proyectan los sefardíes en el cambio de los siglos XIX-XX se revelan en las conclusiones de Asenjo en su estudio sobre los artículos periodísticos publicados en el periódico El Avenir de Salónica sobre el desastre de 1898: «El discurso en torno a España proyecta una imagen contradictoria (a la vez positiva y negativa: el español es «curajoso»y arrogante; huye de la batalla definitiva pero pelea durante horas por un trozo de tierra; su bravura le hace mantener una guerra perdida de antemano, cuando la verdadera bravura consiste en pedir la paz) que se basa en parte en los tópicos tradicionales (la España unida en torno a la fe cristiana que hizo sufrir a los judíos es, a la vez, una "nación de caballeros"). Los sefardíes parecen incapaces de cambiar esta visión o de desembarazarse definitivamente de ella» (Asenjo 2005: 28-29).

Respecto a la literatura sefardí contemporánea escrita en judeoespañol, el análisis de Romero revela también esta ambivalencia: de un lado, parece que se insiste en los tópicos de la España desterradora e inquisitorial, pero sólo entre los autores de mayor edad, ya que la idea va siendo desplazada paulatinamente por el desarrollo de un sentimiento de amor-odio, en el que el último se atenúa para dejar paso a una nostalgia del tiempo remoto (2003: 198-199).

Con esos datos en la mano, nuestra intención es analizar a través de los testimonios de los sefardíes cuál consideran ellos su «patria».

\section{EL CONCEPTO «PATRIA»}

Hassán tocó el tema de refilón en un ya añejo pero fundamental estudio y se basó en cuatro topics para analizar a los sefardíes como objeto de tópico para los españoles: la lengua, el romancero, la españolidad y la patria (Hassán 1986). Hassán mencionó, como primero de los tópicos relacionados con el concepto «Patria», el basado en la romántica idea de Pulido de que no pudiendo considerar a España como su patria real, los sefardíes serían los eternos errantes «españoles sin patria». El senador veía en la inmigración sefardí uno de los «intereses nacionales», y abogaba, en plena época de emigración, por que se asentaran aquí (Hassán 1986: 36). En la misma línea, Díaz-Mas ha analizado en numerosos artículos $(2000,2001,2006)$ la repercusión de la obra de Pulido entre los españoles y la reacción sefardí ante la campaña.

La romántica idea cundió en España y se reiteró hasta tiempos recientes. Y contagió a los sefardíes. En las memorias de Moïse Abinun (Sarajevo, 1912), un 
funcionario le proporciona los documentos de identidad en regla a su tío Isaac en Barcelona —en 1936-y le dice:

Je souhaite que bientôt les juifs qui ont quitté notre pays et ont su lui rester fidèles en conservant notre langue reviennent s'installer chez nous. Je suis heureux de vous accueillir (Abinun 1988: 253).

¿Pero de qué «patria» estamos hablando: de la tierra natal o adoptiva ordenada como nación, a la que se siente ligado el ser humano por vínculos jurídicos, históricos y afectivos o al lugar, ciudad o país en que se ha nacido"?

En palabras de Matilde Bensignor (2004: 31): ¿Dónde está la Patria del judío?

- Cuando fui a España y caminé por las callecitas de Toledo, casi lloro de emoción. En Sevilla, escuché el flamenco y sentí que todo mi cuerpo vibraba.

—Entonces, ¿tu patria es España?

—No... Amo el país donde nací. Añoro la tierra de mis antepasados, Sefarad, y siento un amor místico hacia Israel.

—Mira, que son complicados... (Bensignor 2004: 252).

O, lo que es lo mismo: soy sefardí (se siente ligada por vínculos históricos a Sefarad), argentina (lugar al que se siente ligada por vínculos jurídicos, pues es el país en el que ha nacido), y judía (se siente ligada por vínculos afectivos a la tierra de Israel).

Esta es la aseveración fundamental que dejan entrever los escritos autobiográficos: el judío sefardí posee varias patrias, y al contrario de lo que se creía en la España de Pulido no sentían necesidad de decantarse por una, sino por abrazarlas todas:

Je n'ai jamais éprouvé l'envie de retourner en Tunisie. Tout d'abord parce que je ne suis pas spécialement attaché au passé, et la Tunisie n'est pas ma terre natale. Comme vous savez, mes racines sont multiples: La Judée, l'Espagne, la France, la Tunisie (Mostrel 2006: 99).

Además, la de una persona podía no coincidir con la del vecino, ni siquiera entre los miembros de un mismo núcleo o clan familiar, pero difícilmente varía

\footnotetext{
${ }^{11}$ Estas son las dos acepciones que para patria da el Diccionario de la Real Academia (DRAE) (www.rae.es).
} 
en orden de importancia. Algunos creen, además, que no se trata propiamente de patrias, sino de matrias. Vidal Nahum, padre del filósofo Edgar Morin (París, 1921), decía poseer cuatro: España, Salónica, Israel y Livorno (Morin 1989: 314). En esa pluralidad de patrias o matrias - alguna matria se ha convertido en madrastra - se han movido tradicionalmente los sefardíes orientales. Casi ninguno deja de preguntarse en algún momento quién es o de dónde es, y es entonces cuando se argumenta al respecto.

Y esto es lo que se desprende: En orden de importancia, el judío sefardí es en primer lugar judío, en segundo sefardí, y luego, lo que se tercie. Una frase que resume lo dicho es esta pronunciada en Bulgaria en los aledaños de la Segunda Guerra Mundial en relación con el origen de una cierta profesora de francés:

Französin. Nein, keine Französin, sondern eine Jüdin, aber aus Frankreich (Arditti 2002: 75),

y que compendia muy bien el abuelo del narrador de El Laberinto de Sión:

No debemos olvidar que por encima de todo somos judíos, y si lo olvidamos no tardarán en recordárnoslo nuestros enemigos (Barnatán 1986: 77).

El vínculo afectivo no es propiamente un lugar terrenal sino un legado patrimonial inmaterial: el judaísmo. La tierra natal o adoptiva ordenada como nación a la que se sienten vinculados por vínculos históricos suele coincidir con Sefarad - aunque progresivamente, a medida que transcurre el tiempo, ese vínculo se desplaza hacia otros países, como tendremos oportunidad de ver-. El vínculo jurídico es el que se crea a partir de la segunda de las acepciones del DRAE para patria, pues la tierra natal o adoptiva ordenada como nación es el lugar, ciudad o país en que se ha nacido y que, como tal, concede en ocasiones la ciudadanía y la nacionalidad (o Estado propio de la persona nacida o naturalizada en una nación ${ }^{12}$ ), pero que en el caso de los sefardíes no necesariamente coincide con la patria. Tradición (judía) e historia (hispánica) se unen en el legado sefardí invocando dos patrias que poco tienen que ver con la nacionalidad que ostentan.

\section{Los VÍNCULOS AFECTIVOS}

La inclinación afectiva nos lleva al primer elemento esencial de la identidad sefardí. Sefarad es la patria histórica que define como pueblo a los sefardíes en

\footnotetext{
${ }^{12}$ Esta es la segunda de las acepciones que para nacionalidad da el DRAE.
} 
el origen inmediato, pero antes de Sefarad hubo una tierra en Palestina que les perteneció: la tierra que Dios prometió a Abraham (A tu simiente daré esta tierra, Ge 12:7; Yo soy el Eterno, que te trajo desde Ur de los caldeos para darte esta tierra que heredarás, Ge 15:7).

Luego, Abraham selló en esa tierra su Alianza con Dios por medio del Pacto de la circuncisión (Y estableceré Mi Pacto contigo y tu simiente después de ti en todas sus generaciones. Será un Pacto eterno: Yo seré Dios para ti y para tu simiente después de ti, Ge 17:23) y sus descendientes así lo han practicado durante generaciones. Jerusalén es la patria espiritual de todo judío, desde siempre y, especialmente, desde los tiempos de Nabucodonosor, cuando se produjo la primera diáspora judía, como tan bellamente se reproduce en el canto Va, pensiero del Nabucco de Verdi ${ }^{13}$. Esa es una constante en todas las memorias, aunque casi ninguno recuerda esa «primera diáspora judía» y sí, en cambio, la segunda:

Chassées de leur patrie spirituelle après la destruction du Temple par les romains, ont erré, dispersés dans le monde tout en sauvegardant à travers leur exil, leur spiritualité juive que seule la mémoire a su maintenir (Karako 2001: 83-84).

Abinun (Sarajevo, 1912) se pregunta con 14 años:

Peut-être n'étions nous pas des Serbes depuis toujours comme je l'entendais également dire, par mes proches, de manière contradictoire? Nos tatarannonus venaient d'ailleurs. Ailleurs, c'était l'Espagne d'abord. Et avant? Qu'était cette Éthiopie? Ce pays de Canaan? (Abinun 1988: 150).

Solal es el desmesurado personaje protagonista de la novela de Albert Cohen (Corfú, 1895), Solal. Judío, seductor, irónico y gran príncipe. Pertenece a Oriente, a la isla de Cefalonia, la mayor de las islas jónicas, pero es un conquistador de Occidente y, sobre todo, de sus mujeres, que le conducen a mil periplos. Tras uno de ellos, interroga a un correligionario que encuentra en la calle: «¿Debo regresar a casa?».

Oui, chez toi, fils. Ou à Jérusalem. Il n'est meilleure place. Quand j'aurai de l'argent, à Jérusalem j'irai, certes à Jérusalem (Cohen 2007a: 111).

Esta patria espiritual judía, sin embargo, no deja de tener una aureola de fatalidad histórica, pues no se puede elegir voluntariamente y es irrenunciable. En este sentido, he aquí el testimonio de Adèle-Rivka Cohen (Bruselas, 1939):

\footnotetext{
${ }^{13}$ Donde se canta la historia del exilio judío en Babilonia tras la pérdida del Primer Templo de Jerusalén. Según libreto de Temistocle Solera (1815-1878): Oh mia patria sì bella e perduta!
} 
Je me sentais, me savais ancrée belge dans toute ma culture juive. Je m'identifiais juive dans l'opulence du littoral flamand, juive dans les soubresauts des paysages ardennais [...]. Je suis juive et reste seulement la Juive, l'étrangère, malgré ma naissance, mes décennies de connaissances bruxelloises (Cohen 1996: 117).

En el seno familiar judío se concede a la madre un papel dinámico, creador y transmisor de valores. El status legal de un niño está determinado por el de la madre. Si ella es judía, su hijo es judío. Si no, el hijo no es judío, aunque lo sea el padre. Y así, de generación en generación hasta tiempos bien recientes, cuando las nuevas corrientes en el seno del judaísmo propugnaron la aparición de la figura del judío laico.

Con todo, también tenemos muchos ejemplos de familias sefardíes que se dicen religiosas, pero no piadosas en extremo. Es el caso de la familia de Elisa Franco-Hasson (Rodas, 1926). Pese a ser su padre presidente de la comunidad, la familia era liberal; seguía las tradiciones sin concederles demasiada importancia. Respetaban el šabbat, pero sin fasto; seguían las fiestas por costumbre. Según la autora —-superviviente de Auschwitz-, la religión no dejó trazos profundos en ella, tal vez porque pasó por unas experiencias que la alejaron de la fe, y que han influido en sus hijos: son judíos, pero con moderación. No obstante, reconoce que le gusta ir en peregrinación cada año al Kótel Hamaarabí ('Muro Occidental' o 'Muro de las Lamentaciones') de Jerusalén (Franco-Hasson 1996: 179).

Ciertamente, la práctica de la religión en las comunidades orientales no era difícil. La vida se estructuraba en torno al eje familiar patriarcal que regían los rabinos en la sombra. Es en la emigración cuando se empieza a cuestionar el rigor de la práctica sinagogal o de la observancia de la cašrut ('pureza ritual en los alimentos'), que muchas veces se explica por la dificultad intrínseca que supone. Por ejemplo, en el Congo:

Il est difficile de manger du poisson ou des œufs tous les jours et il n'y a pas encore de congélateur pour conserver viandes et volailles égorgées rituellement [...]. L'attachement à ce qui est juif et à Israel est fervent mais le judaïsme est tiède (Rahmani 2002: 171-172).

Otra particularidad que se recoge en relación con esa patria afectiva y espiritual es la peregrinación en la vejez a la ciudad santa para ser enterrado en el Monte de los Olivos, al este de la Ciudad Vieja. Desde allí, según la profecía de Zacarías, el Mesías comenzará a redimir a los muertos al final de los tiempos ( $Y$ sus pies se posarán ese día sobre el monte de los Olivos, que está delante de Jerusalén, al oriente, $\mathrm{Za}$ 14:4). Esta es una costumbre que se ha mantenido entre los sefardíes desde los tiempos bíblicos. 
Los bisabuelos de Vittorio Alhadeff (Rodas, 1904), Hadji Bohor y Vava Esther, partieron de Rodas a Jerusalén en 1875. Murieron allí a pocos días de diferencia; primero Hadji, después Esther, según su deseo (Cuando sea la hora, quiera Dios que él se vaya primero, antes que yo). También sus abuelos Papu Yaco y Vava Raquel partieron en el año 1890. Todos están enterrados en el cementerio del Monte de los Olivos (Alhadeff 1998: 39-42 y 54).

En 1912, el año en que Kırklareli (en la Turquía europea) se unió a Europa por tren por el oeste y a Estambul por el este, el año en que se abrió allí la primera escuela de la Alliance, el bisabuelo de Erol Haker (Estambul, 1930), Menahem Adato, decidió ir a retirarse a Jerusalén para hacer vida de estudio y plegaria. Se fue en uno de los primeros trenes. A partir de entonces, la ciudad de Kirklareli se convirtió en el escenario de cruentas luchas que durarían hasta 1922, con el fin de la guerra por la liberación de Turquía (Haker 2003: 12).

En 1960, los padres de Víctor Perera (Guatemala, 1934) regresan desde Guatemala a la Jerusalén que les vio nacer. En este caso, la vuelta era doblemente sentida, pues regresaban a su lugar de origen al final de sus días. El propio Víctor reconoce que ellos eran judíos sólo de nombre y que sólo en su vejez decidió el padre volver a la práctica religiosa y al cultivo de su identidad, pero le duró poco, porque falleció a los pocos meses de instalarse en Israel (Perera 1996: 246).

En resumen, el concepto de patria afectivo-espiritual en los escritos autobiográficos vuelve la vista a una «patria» más lejana que la Sefarad medieval: Jerusalén, cuna y esencia del judaísmo, aún cuando: «they persist in 'feeling Jewish', even if their Jewishness does not lead to their living day to day much different from other non-Jews» (Schorsch 2007: 117).

\section{LOS VÍNCULOS HISTÓRICOS: TRASLACIÓN DE LOS PATRONES MITIFICADORES}

Los testimonios modernos mencionan abrumadoramente a España en sus escritos, pero con matices: mientras en las historias familiares (saga) que cubren varios siglos (Shaltiel-Gracian, Perera) la injerencia de España en la narración es casi obligada; en las historias personales (Gord, Serotte) no es esencial en sí misma. En aquéllas, los temas favoritos siguen siendo la expulsión de 1492, la inquisición, y el antisemitismo español. En las historias personales, los autores los mencionan en ocasiones, aunque reflejan sus opiniones más libremente, a veces en prolijos excursos, pero no son el objeto de su discurso.

La conciencia de la procedencia hispánica de los sefardíes se mantuvo muy viva en la memoria colectiva y en la tradición oral. Por lo general mantienen 
intacta una imagen mítica de la remota Sefarad medieval — la que determinó un salto cualitativo en el desarrollo histórico del judaísmo- y se sienten orgullosos de su herencia ${ }^{14}$. Los estereotipos nos conducen a esa «patria» lejana a la cual los sefardíes se enraizaron espiritualmente desde 1492. Rememoran la expulsión ofreciendo datos más o menos certeros sobre las circunstancias que la precedieron, pero varía el aprecio de los elementos identitarios que definen la herencia en la diáspora. En la búsqueda de su sefardismo cobra relieve el rastreo de las propias raíces hasta encontrar el ancestro o el lugar de procedencia peninsular.

Los testimonios reflejan la relación ambivalente de los sefardíes con respecto a Sefarad: por una parte, la mitificación del pasado histórico, debida sobre todo a la idea (transmitida por tradición de generación en generación) de que los asentamientos judíos en la Península Ibérica tenían una venerable antigüedad y que la cultura judía alcanzó durante la Edad Media peninsular un momento de singular esplendor. De ahí surge un cierto sentido aristocrático sefardí (cfr. Papo 2006: 158), que lleva a la construcción de leyendas familiares sobre la supuesta conservación de las llaves de la casa abandonada a raíz de la expulsión, o a un prurito genealogista, de búsqueda de orígenes familiares a través de los apellidos y de la construcción de una genealogía prestigiosa, a veces por descender de personajes históricos relevantes, a veces por la identidad de apellidos con topónimos peninsulares. Como ejemplo de genealogía prestigiosa puede mencionarse la de la familia Shaltiel, que dice descender de la Casa de David:

Mochon [el abuelo del autor] told my father that the family had lived in Salonika for hundreds of years, and before that, they had lived in Spain, where the Shaltiels were highly respected, not only for their wealth but because they were descended from the House of David. According to my grandfather, the family had its own coat of arms, a testament to their royal origins, and was the only armigerous Jewish family in Spain (Shaltiel-Gracian 2005: 12).

Jacques Abravanel (Salónica, 1906) dice descender de un personaje histórico relevante, Don Isaac Yehudá Abravanel (y por medio de éste también del rey David):

Mon père, Joseph Jacob, descendait en ligne directe de l'illustre Don Isaac Yehuda par son fils aîné, Don Leon, connu sous les noms de «Leon Hebreo» et «Leon El Medico», dont le fils aîné [...] était venu s’installer à Salonique au début du XVIème siècle (Abravanel 1999: 9).

${ }^{14}$ En el mismo sentido SchORSCh (2007: 115-116). Ilustrativos y complementarios en este sentido son los estudios compilados por BЕСКwITH (2000). 
Y de la española ciudad de Cuenca desciende la familia de Sylvie CourtineDenamy (París, 1947). Sus antepasados vivieron en Salónica, pero la familia próxima nació en Constantinopla y, luego, se trasladó a París. Rebeca Nahmías, su abuela materna, era de Varna (Bulgaria). Asegura que la familia es originaria de Cuenca (Courtine-Denamy 2001: 19). Su antepasado se llamaba Juan Cuenca, fue condenado por la inquisición y murió en 1490 quemado en efigie en un auto de fe. Su nieto, Johancho de Cuenca es quien emigró en barco desde Cartagena a consecuencia del Decreto de Expulsión y llegó con su esposa Isabel a las tierras del Gran Turco con la primera oleada migratoria (Courtine-Denamy 2001: 39-48). Para Courtine-Denamy, como para Shaltiel-Gracian y GrazianiLévy —quienes dicen ser originarios de Cataluña—, la búsqueda de sus raíces es su objetivo primordial.

Esa imagen mítica no es siempre positiva. Ya advirtió Hassán (1986: 35-36) que la actitud de la minoría hispanófila sefardí no es exportable a la totalidad «porque la generalidad de los sefardíes, con todas las salvedades que se quiera, lo que alberga hacia España es un sentimiento de despego, casi pudiéramos decir que de hostilidad hacia ese nebuloso país que es "Sefarad"», pero se calló las anécdotas al respecto que dijo atesorar.

Junto al recuerdo de ese esplendor ha pervivido hasta hoy entre los sefardíes la memoria histórica de la cara amarga de ese mismo pasado, que les hace ver España como el país de las persecuciones inquisitoriales y la expulsión decretada por los reyes. Lo que para las primeras generaciones de expulsos fue una experiencia traumática, se ha ido ficcionalizando hasta cristalizar en un discurso estereotipado que repite una y otra vez los mismos lugares comunes:

It was then [in Barcelona], sitting comfortably in the [Hotel] Colon [...]. A painful thought penetrated my mind. I was looking at the descendants of the people who, in this very place, near the Cathedral and beyond it, in the Calle (sic), the Jewish Quarter, killed and burned, and in their mad religious fervor destroyed, an entire Jewish community. Among the dead, members of the families of the Nesiim of Barcelona, my ancestors. Then I had another thought: the fathers of these people, the dancers and the crowd, not only had Jewish blood on hands, but the same people had the same blood -our fathers' blood—in their veins. It had all happened 600 years ago, but as I sat on my balcony, it seemed as though it could have happened yesterday (Shaltiel-Gracian 2005: 119).

En las mujeres de la familia se notaban también viejos resquemores y suspicacias hacia un país clerical en el que la Inquisición se había entregado a todos los desmanes imaginables (Papo 2006: 159). 
Car un homme terrible nommé Torquemada avait décidé de les forcer à changer de Dieu, ou, s'ils refusaient, de les chasser de cette Espagne où ils avaient vécu heureux pendant plusieurs siècles (Gord 2000: 15).

En el siglo XX, para la mayoría, España era uno más de los países posibles que pudiera ofrecerles garantías diplomáticas y las más de las veces era elegido por razones pragmáticas, no por considerarlo su «patria», ni siquiera remota. Dejando de momento de lado las cuestiones de nacionalidad, que examinaremos en el epígrafe siguiente, veamos algunos ejemplos de los que emigraron a España.

Moïse Abinun (Sarajevo, 1912), sastre de profesión, es enviado a casa de su tío Isaac en Barcelona en 1936, con el fin que conozca a la hija de este, Mathilde, y trate de comenzar allí una nueva vida. Moïse y Mathilde se casaron, pero se establecieron en Francia justo cuando iba a comenzar la guerra civil española (Abinun 1988: 244-260). También la familia de Harry Moreno (Sofía, 1929) se estableció en Barcelona en 1952. Eligieron esa ciudad porque un familiar de su madre vivía ahí desde hacía tiempo (Moreno 2003: 320-323). Razones de índole puramente económica trajeron a la familia de Samuel Mordoh (Atenas, 1939) a España en los años 50:

«Voy a intentar establecerme en un país de Europa, Italia, Francia u otro. Si voy a Italia tengo suficiente dinero ahorrado para vivir tres meses sin trabajar. Si voy a Francia tengo para otro tanto. Pero si voy a España, especialmente después de esta oferta de Julio, tengo suficiente para vivir un año». Así que la decisión estaba tomada: se iría a España para intentar forjar una nueva vida para él y su familia (Mordoh 2003: 270).

Y de índole política a la familia de Isaac Papo (Milán, 1926). Los Papo llegaron a Barcelona desde Milán en 1942, con sus pasaportes españoles, huyendo de la guerra, aunque poco o nada sabían del país donde se dirigían:

En mi familia, de España no sabíamos prácticamente nada: hasta un cierto momento nos parecía lejanísima, como si perteneciera a otro continente. [...] No había pues ningún motivo cultural, económico o simplemente afectivo que nos acercase a España, y así pensaba la inmensa mayoría de los sefardíes hispano-parlantes (Papo 2006: 159).

Del mismo modo fue fortuita la elección de otros países:

Le 11 août 1927 [...] tu t'embarques seul, papou [...]. Parcourant l'Europe, tu cherchais, semble-t-il, le meilleur endroit pour implanter la famille. [...] Ton voyage dura trois mois: Après Paris, l'Italie, la Suisse, la Bulgarie, la Russie (Courtine-Denamy 2001: 88). 
España cobró relieve en el tránsito entre las dos últimas etapas que cubren los escritos autobiográficos de los sefardíes: la de emigración y reasentamiento y, especialmente, en la de afirmación en la Segunda Diáspora. Es entonces cuando se ve como un destino posible y muchos recalan aquí tratando de encontrar no sólo sus raíces, sino su pasado, tratando de aggiornarlo y darle una dimensión de cercanía, como si el pisar suelo hispano fuera cuestión de habitualidad. Es en ese descubrimiento de la España contemporánea cuando los antiguos mitos dejan paso a nuevos sentimientos que mitigan el odio atávico, y combinan en sabia proporción el orgullo ancestral con el amor renovado que ahora dicen sentir.

En general, esa doble visión positiva y negativa de la «patria sefardí» se debe también a una tradición oral transmitida en el seno de las familias, pero que es compatible con el más absoluto desconocimiento, tanto de la España actual como de su historia, e incluso de su propia historia como pueblo ${ }^{15}$. Algunas veces, especialmente en las novelas, los incursos a los orígenes peninsulares se utilizan como recurso literario: La familia Moreno huye de Salónica hacia el Norte a principios del siglo XX. Un anciano les acoge en el camino e, interesándose por su historia, le pregunta al abuelo Haim: «Y eso de sefardí, ¿qué es?». Aprovecha entonces el autor para interpolar una breve historia de los judíos sefardíes (Moreno 2003: 23-24).

Pero, sorprendentemente, aunque menos habitual, tenemos también el reverso de la moneda. Para Kastoryano (Estambul, 1931), España parece no existir ni en el mapamundi. Víctor Perera (Guatemala, 1934) — de familia de origen jerosolimitano pero afincada en Guatemala-, menciona España sólo para remontarse a su ascendencia, pero en ningún momento aparece la España contemporánea, aún viviendo en un país de habla hispana (Perera 1996: 34 y 57). La abuela de Ángel Wagenstein (Plovdiv, 1922), con quien el autor vivió en su infancia, desconocía, como el resto de sus coetáneas, su propia historia como pueblo y la propia palabra «España» no le producía ningún sentimiento especial:

Ma grand-mère ne savait rien de tout cela et n'en avait même jamais entendu parler, tout prétendu lien spirituel et linguistique avec l'Espagne

${ }^{15}$ Como ya notara Arié a finales del siglo XIX. En varias ocasiones menciona que los sefardíes desconocen su propia historia. Entre ellas, en una carta dirigida a la Alliance Israélite Universelle de 7 de febrero de 1890. A propósito de haber hecho un pedido de libros de historia para la escuela, que a él le interesan, dice que quiere escribir una historia sobre los sefardíes — que escribió al final refundiendo las de otros autores-, porque desconocen su propia historia y la de España. Asimismo señalaba que los sefardíes deberían preguntarse si querían festejar la conmemoración de la expulsión en 1892 porque la realidad era que los estudiantes no sabían más sobre España que sobre los chinos e hindúes (BENBASSA \& RodRIGUE 1992: 167-169). 
la laissait de marbre [...]. Il était donc question de ma grand-mère qui ne savait rien de sa propre histoire, ni de celle de ses voisines, des Juives aussi ignorantes qu'elle (Wagenstein 2005: 14-15).

Extremo es el caso de Gabriel Arié (Samacof, 1863), profesor de las escuelas de la Alliance en Balat, Esmirna y Sofía. Dice no sentir ninguna nostalgia por España o por lo español, pese a haber adquirido la nacionalidad española gracias al Decreto de Primo de Ribera de 1924 y haber sido condecorado con la Orden de Isabel la Católica, lo que no deja de ser una paradoja. Pero tampoco tenía ningún sentimiento patriótico por Bulgaria. Al contrario, ninguna expresión de disgusto sale de su boca cuando ve a familiares que se van a buscar la vida lejos: «S'il était sensible à l'antisémitisme bulgare, il ne pouvait prétendre que, de ce point de vue, la situation fut pire qu'ailleurs. Au contraire, le bilan bulgare sur ce point était relativement positif, et le judaïsme bulgare n'eut pas à souffrir de persécutions majeures jusqu'à la Shoah. Et pourtant, en continuité directe avec la période ottomane, rien ne montre comme de vrais bulgares ou qu'ils se soient en fait eux-mêmes considérés comme tels» (Benbassa \& Rodrigue 1992: 35).

Menos extremo, aunque no menos certero de lo que ocurría en realidad entre los sefardíes, especialmente entre la burguesía acomodada, es el testimonio de Isaac Papo (Milán, 1926):

En el mapa mental de la generación de mis padres se otorgaba un mínimo espacio al tema «España». Además de inmaterial, era intrascendente, y seguía siéndolo hasta que los avatares de una época aciaga nos hicieron tropezar con una realidad en ocasiones mencionada pero jamás conocida. [...] Lo referente específicamente a España, o más propiamente a «lo español» en general, tenía en nuestras conversaciones un carácter tópico, con todas las aproximaciones orientales habituales aplicadas a todo lo que no estaba escrito (Papo 2006: 157).

Y si en la burguesía acomodada esa era la situación, no es difícil presumir que para la mayoría «desacomodada» el tema carecía en absoluto de importancia.

Otros autores explicitan su desconocimiento debido a múltiples razones. Shaltiel-Gracian, por ejemplo, educado en Israel, dice que en su infancia en las escuelas, la cultura sefardí parecía no existir. Cuando su padre le hablaba de sus antepasados en Sefarad, descubrió que no sabía nada. Pero tampoco lo sabían sus familiares salonicenses. Cuando el autor fue allá para investigar sus orígenes, reunieron en una comida a 35 Saltieles y el autor pudo comprobar cómo sólo los más ancianos hablaban ladino y la mayoría no sabía nada de sus raíces españolas. Eran de cultura occidental, su lengua era el griego y políticamente eran griegos (Shaltiel-Gracian 2005: 52). 
Pero incluso entre personas que sí han conservado sus raíces, estas no se han transmitido familiarmente. He aquí el caso de una mujer que ha manifestado recientemente a través de la virtual Ladinokomunita que nunca habló a su familia acerca de su origen y que sólo cuando su nieto Aroniko (20 años) hubo de entrevistar a una persona no nacida en los Estados Unidos para un trabajo de clase, se acordó de su abuela:

Aaroniko penso a mi, se kedo kon la boka avyerta kuando ampesi a dizirle no solo de mi, ma de mi padre ke era de la Italia ke se enkontro kon mi madre en Estanbol, ke se fuyeron a Bulgariya, ke se kazaron ayi. Ke mi ermana i yo nasimos en Filibe (Plovdiv), agora ke pasimos por Estanbol en 1938 para irmos a Palestina i kedimos ayi. Le konti ke porke eramos suditos Italianos tuvimos mi ermana i yo de azer muestros estudyos en un konvento de Sores katolikas. Aaroniko se asperava ke le iva a kontar solo por mi venida de Estanbol, no se lo asperava ke le iva a kontar ampesando de mi padre ${ }^{16}$.

La emigración fue, por lo general, irreversible. Es entonces cuando los sefardíes de la Segunda Diáspora ceden a la nostalgia, no ya de Sefarad, sino del buen viejo tiempo ${ }^{17}$ oriental, cuyas formas se reprodujeron en Occidente hasta la Segunda Guerra Mundial, de modo que la generación transplantada vivió - y en parte sigue viviendo- en una poli-identidad oriental-occidental. He aquí unos ejemplos.

El tío de Isaac Papo, Samuel, fue uno de los que hubo de regresar a Oriente después de quedar completamente arruinado:

Sólo mi tío Samuel, completamente arruinado y sintiendo aproximarse el fin de sus días -que tardó sólo unos meses-, quiso volver y hacerse cargo de una pequeña hilatura que poseía en Sufli. El antiguo compañero de Talaat Pachá era en su fuero interno un hombre del buen viejo tiempo, a pesar de su aparente occidentalización y de los años pasados en la buena sociedad de París (Papo 2006: 43).

Victor Farhi, nacido en Estambul, vive en Cleveland (USA). Mantiene con Lidya Kastoryano (Estambul, 1931) una conversación telefónica en 1988 y se emociona al hablar de su madre y de «su país de origen»:

Il pleurait presque au bout du fil en lui disant combien était grande sa nostalgie pour son pays d'origine, comment en parlant avec elle, tous les tendres souvenirs, enfouis dans l'oubli volontaire, remontent à la surface. Combien il

\footnotetext{
${ }^{16}$ Mensaje enviado a Ladinokomunita el 27 de noviembre de 2007.

${ }^{17}$ Auld Lang Syne (lit. 'buen viejo tiempo'), poema de Robert Burns (s. XVIII).
} 
regrettait, en vieillissant, de n'être qu'un émigré, loin des tombeaux de ceux que l'on a toujours aimés. Il lui avoua aussi, qu'il était peiné de savoir ses parents séparés, après leur mort, sa mère étant enterrée à New York, et son père à Arnavuköy à Istanbul (Kastoryano 1993: 184-186).

Y muchos son los que sueñan nostálgicamente con aquel paraíso perdido que dejaron atrás y que no existe más:

Vidal vécut une poly-identité orientale-occidentale [...]: Salonicien d'abord, Salonicien surtout, enfant de Salonique, petite mais vraie patrie devenu paradis perdu (Morin 1989: 452).

They may have been sentimental for Espanya in song, but it was for Turkey that they retained a deep, nostalgic longing. All of them practiced being Americans but remained Turkish to the bone (Serotte 2006: 27-28).

Me duele la memoria... [dice Betty Rosanes pensando en su ciudad natal, Sofía] (Gutkowski 1999: 136).

When she speaks about Turkey from her home in London she is full of love and nostalgia, highly enthusiastic about Atatürk's accomplishments (Kohen 2004: 95).

À Salonique, nous sommes chez nous [dice Moïse, cuñado del protagonista, Bohor] (Lagardet 2007: 366).

De la voz de mi padre brota una suave nostalgia; nostalgia de su tierra [Monastir], de sus aguas; nostalgia de familia, de amigos, de calles (Nizri 2000: 31).

A mayor abundamiento, en la obra de Sam Bension Maimon (Brusa, 1907), la expresión old country aparece muchas veces para referirse única y exclusivamente a Turquía.

De las memorias más recientes, la mayoría escritas por personas que nacieron ya fuera de los países turco-balcánicos, se desprende que en la nueva diáspora occidental se están reproduciendo los mismos patrones mitificadores que se produjeron después de 1492, sólo que ahora apuntan a otros lugares. Si durante 400 años Sefarad fue el paraíso perdido, ahora son los países de la diáspora primaria los que vienen a reemplazar el antiguo arraigo hacia Sefarad. Por ejemplo, Adèle-Rivka Cohen (Bruselas, 1939) califica a España de «severa y altiva» frente a la «deslumbrante» Turquía (Cohen 1996: 18). Quién sabe si en pocos años la herencia de Sefarad se diluirá en un pasado tan remoto como lo fue la tierra de Israel durante el Medioevo. 
LOS VÍNCULOS JURÍDICOS: EL PAÍS O LUGAR DONDE SE HA NACIDO

Para los sefardíes, la «patria» raras veces coincide con la «nacionalidad» que ostentan, especialmente a partir de principios del siglo XX, con el desmembramiento del Imperio otomano y la emigración a otros países. La nacionalidad, entendida como condición y carácter peculiar de los pueblos y habitantes de una nación, es aplicable a los judíos en general en tanto ellos han sido siempre una nación, aunque sin territorio, durante siglos.

La nacionalidad política que vincula jurídicamente a un país haciéndoles sujetos de derecho y, por tanto, sujetos a derechos y obligaciones, es algo a lo que los sefardíes se han aferrado por necesidad. Pero la nacionalidad tampoco coincide entre ellos con el Estado propio de la persona nacida o naturalizada en una nación, pues aún habiendo nacido en Turquía pueden ser súbditos franceses, o viviendo en Bulgaria ser súbditos griegos. Además, en el Imperio otomano siempre constituyeron una minoría, como los armenios o los griegos, y estuvieron sujetos al régimen de millet desde mediados del siglo XVIII.

Así, mientras los vínculos de la tradición y la historia son para los sefardíes inalienables e irrenunciables, la nacionalidad no lo es. El Estado no es una patria. Esto se traduce, por ejemplo, en que cuando se impuso el servicio militar obligatorio en Turquía (askerlik) tras la Revolución de los Jóvenes turcos (1908), los jóvenes emigraron masivamente a otros países o bien trataron de acomodarse en alguna de las antiguas nacionalidades familiares para librarse de él. Sentían los malestares de los turcos, pero no estaban integrados en su sociedad:

N'ayant pas à donner nos fils par la défense d'une patrie commune, leurs désastres ne pouvaient être les nôtres. [...] La pluralité des juifs espagnols vivaient sans le moindre notion de politique, attachés au pays par cet amour candide de la tradition et les habitudes (Caraco 2002: 10).

En tiempos de Abdul Hamid se podía evitar el servicio militar pagando una cantidad, un bedel, pero la situación cambió con la Revolución de los Jóvenes Turcos. El tío de Vittorio Alhadeff (Rodas, 1904), Acher, resultó afectado. Se sacrificaron pollos para pedir clemencia a Dios; la familia lloraba al unísono. ¿Cómo podría sobrevivir Acher, de natural delicado, en las planicies de Anatolia? Nadie supo exactamente cómo, pero gracias a las gestiones de un familiar, consiguieron la eximente para Acher (Alhadeff 1998: 106-107).

También para evitar alistarse durante la Primera Guerra Mundial: 
Seventy five percent of the unmarried men, in their late teens or who already were in the market in their early twenties, emigrated between the end of the Second Balkan War in July 1913 and June 1914, two months before de First World War broke out (Haker 2003: 123).

Concretamente, Lía Adato - abuelo de Haker- organizó en Kırklareli (Turquía europea) un sistema para eximir a los judíos del reclutamiento. Cada uno pagaba una tasa, que era igual para todos independientemente de sus ganancias. Todos los judíos de Kurklareli eran declarados exentos debido a razones de salud. Lía consiguió incluso, por amistad, que un amigo turco pasara por judío y lo declararan no apto. La comisión de reclutamiento para los diversos frentes del Imperio quiso organizar una comisión para investigar las causas de la mala salud de los judíos de Kırklareli... El propio Lía se hizo pasar por epiléptico con un plan trazado para escapar del servicio militar — que significaba luchar en el frente de guerra-, al que fue llamado en noviembre de 1915. Varios amigos le ayudaron, entre ellos un militar turco, y consiguió lo que deseaba (Haker 2003: 130-131).

Lo propio ocurrió con el establecimiento de la República de Turquía en 1923, década en la cual la emigración se veía como la única salida posible. De ahí que el Real Decreto de Primo de Rivera de 20 de diciembre de 1924, por el que España reconocía el derecho de los sefardíes a adquirir la nacionalidad española, fuera una inestimable tabla de salvación para muchos, como para algunos miembros de la familia Shaltiel:

There are few prophets, and the Sephardim of Salonika were no exception: they chose their fate, twenty years before the war, because of mundane considerations like taxes, the nuisance of annual registration, and military service. They could certainly never have anticipated that in the early 40 `s, that relatively casual choice would spell the difference between life and death (Shaltiel 2005: 80).

Caso curioso es el de Jacques Abravanel. De nacionalidad portuguesa, en Turquía no hace el servicio militar por ser portugués, y en Portugal tampoco, por ser residente en el extranjero. Al fin, se le declara exento mientras está viviendo en Portugal, debido a que va a ser nombrado cónsul de Portugal en Turquía (Abravanel 1999: 65).

Sin embargo, después de la Segunda Guerra Mundial, son ya bastantes los que testimonian que sirvieron a su país: Henry Levy en Grecia (Santa Puche 2003: 133), y Alfredo Papo en España (Berthelot 2001: 492), e incluso son varios los que, como Stella Hasson, certifican un patriotismo que les definiría como súbditos integrados: 
Les Juifs, tout comme les autres italiens, faisaient preuve d'une fidélité et d'un patriotisme à toute épreuve à l'égard du gouvernement et de son dirigeant (Hasson 2007: 28).

En la emigración se observa una urgencia por alejarse del pasado que implica siempre sufrimiento, ya sea por la violencia o por las malas condiciones de vida. Especialmente los que emigraron a América destacan el espacio americano como el lugar donde pueden realizarse sus expectativas y donde es casi intrascendente poseer una u otra nacionalidad. No así para los que quedaron en Europa, que en pocos años se vería inmersa en la persecución nazi.

El siglo XX es para los judíos sefardíes el del baile de nacionalidades y el microcosmos de nacionalidades que se crean en el seno de una misma familia, a tal punto que en cada rama familiar hay elementos con distintas nacionalidades, que cambian o recuperan según el ritmo de los acontecimientos históricos mundiales.

Buenos ejemplos son los de la familia Shaltiel, donde conviven italianos, griegos y españoles (Shaltiel-Gracian 2005: 61), y de la familia de Edgar Morin (París, 1921) —-francés por nacimiento-, que tiene en su seno una salade macedonienne de nacionalidades ${ }^{18}$, una especie de tribu que aúna a todos y cuyo rasgo más característico es el cosmopolitismo: de Liorna a Alejandría, a Skopje, Belgrado, Viena o París. Esta es una de las obras donde mejor se describe este trasiego a través de las cuatro familias que componen el árbol genealógico: los Nahum-Frances y los Beressi-Mosseri. La familia paterna procedía de gente alta livornesa. La rama Beressi estaba instalada en Salónica desde siglo XVIII, y los Mosseri eran también de origen livornés. Parte de los Beressi se encontraban en España desde principios del siglo XX. En la generación de Vidal, padre de Morin, parte de la esa rama reside en Bélgica y Belgrado.

El abuelo de Morin, después del tratado ruso-turco tras la guerra de 1878, adquirió la nacionalidad italiana aunque estaba completamente salonicizado. Sus hijos Vidal y Henry huyen a Francia y son internados en la abadía de Frigolet durante la Primera Guerra Mundial. A su liberación, obtienen un papel de identificación donde indica: «nacionalidad italiana». Escriben a su padre a Salónica que no desean ser declarados italianos, pero el mensaje es interceptado por la policía. Deben decidir solos:

Se déclarer italiens, c'était se faire envoyer dans l'armée italienne, se déclarer grecs, c'était se faire renvoyer à Salonique; se déclarer turcs, c'était

\footnotetext{
${ }^{18}$ Así califica la cuestión el Presidente del Consejo de Diputados francés, Aristide Briand, cuando pregunta acerca de la identidad nacional de los Nahum en plena guerra mundial (MoRIN 1989: 100-101).
} 
se faire arrêter comme ressortissants ennemis, se déclarer belges, c'était se faire incorporer dans l'armée du Roi-soldat. Il n'y avait pas le choix pour une autre nationalité, et, du reste, toutes étaient en guerre (Morin 1989: 108).

Todas las opciones eran malas, pues todos los países estaban en guerra. La mejor: Declararse salonicenses. «Vous vous foutez de moi?», declara el comisario que les atiende. Pero son liberados como súbditos salonicenses, y así consta en su permis de séjour. Posteriormente, Vidal borró la inscripción salonicien y escribió israélite du Levant. El estatuto de una minoría emigrada daba todas las ventajas de protección nacional francesa sin los inconvenientes militares de la nacionalidad. Después del incendio de Salónica el 5 de agosto de 1917 hubo que encontrar una fórmula para los refugiados. Así, Vidal pasó de salonicien durante un año, a israélite du Lévant por algunos otros, a griego en 1925, hasta ser declarado ciudadano francés en 1931. Aunque Vidal se siente francés en los años 20 - pues vive en Francia_- cuando debe pedir la nacionalidad en 1925 pide la griega y no la francesa, porque se siente cultural y afectivamente más próximo (Morin 1989: 151-152). Siendo salonicien e israélite du Lévant, los Nahum escaparon al Estado militar y por tanto al servicio militar, tal como había ocurrido con los Nahum de la generación anterior en Salónica (entre 1878 y 1912) por ser livorneses. Y es que «le pire malheur était d'être mobilisé pour combattre au service d'une nation à laquelle on n'appartenait que de façon abstraite» (Morin 1989: 112).

El baile de nacionalidades se acrecentó de modo inusitado alrededor de la Segunda Guerra Mundial, cuando el tener uno u otro pasaporte, o una visa, eran un salvaconducto para la vida o para la muerte en determinados lugares, especialmente en los países que se desgajaron del Imperio otomano y ahora sufrían en mayor o menor rigor el nazismo. Con todo, los ciudadanos de los países balcánicos se identificaron más rápidamente con la lucha por su propio país, tal vez porque habían conseguido su independencia con anterioridad. Por ejemplo, Jamila Kolonomos (Monastir, 1922) y Avram Sadikario (Monastir, 1919) lucharon en la Resistencia en Macedonia.

El padre de Elisa Franco-Hasson (Rodas, 1926) optó por la nacionalidad italiana con anterioridad a la promulgación por Mussolini de las leyes raciales en 1937. Declaró que todos habían nacido en Rodas y todos tuvieron su pasaporte. Decisión sabia que tuvo consecuencias positivas para casi todos los miembros de la familia menos para ella y dos de las hermanas de su madre, que fueron deportadas a Auschwitz el 3 de agosto de 1944 (Franco-Hasson 1996: 11). También en Rodas, Alhadeff (Rodas, 1904) recuerda a los servicios consulares franceses desbordados, con miles de judíos alemanes y polacos a la espera de una 
visa para la dignidad. Vittorio la consiguió por amistad con el cónsul (Alhadeff 1998: 229).

Quienes consiguen la nacionalidad francesa coinciden en testimoniar que es la más bella nacionalidad, pues rima con libertad. Bohor, que se siente «turco español» (Lagardet 2007: 13), tras permanecer varios años en Francia y tras enterarse de la muerte de su madre en Estambul, considera su condición de «emigrado» y decide asimilarse totalmente (Lagardet 2007: 279). Discute Bohor con su amigo Jacob acerca de la procedencia de nacionalizarse francés. Jacob no es nacionalista, cree que los hombres deben saber gobernarse ellos mismos, pero ambos piensan que sus hijos serán franceses antes que judíos, que irán a la escuela de la República y aprenderán francés. Nacerán en un país libre (Lagardet 2007: 281). Tan importante es ese documento para Bohor que cuando arriba a sus manos compra una caja fuerte para guardarlo (Lagardet 2007: 283).

\section{¿UNA O VARIAS PATRIAS?}

Los autores han definido con bastante nitidez que son judíos en primer término y, luego, sefardíes. En cambio, su ubicación en un país moderno concreto suele comportar enormes dificultades y les crea numerosos interrogantes en el momento de definirse. La mayoría ha tenido, además de patria afectiva e histórica, varias nacionalidades y, consecuentemente, varias patrias - aunque fueran sólo jurídicas - en su vida. ¿Elegir una? Arduo para la mayoría.

Dice ya la madre de Moïse Abinun en Sarajevo en el primer cuarto del siglo XX:

L'Espagne, notre pays? Peut-être. La Palestine aussi alors! Tu sais, moi, je suis d'ici, comme mes parents, mes grands-parents... Bien sûr, nous parlons l'espagnol... Mais nos ancêtres ont tout de même dû quitter le pays à toute vitesse! Ici, on n'a jamais eu de problème... La France, c'est un rêve! Même ma mère parlait de ces vistidus a la franca, ces habits à la française; pour elle c'était vague, ça voulait dire: toute l'Europe occidentale! Ça me ferait plaisir d'y aller. Mais, tu sais, mon fils, même pour se rendre dans les pays des droits de l'homme, il faut un billet de train payé en argent comptant et de quoi vivre là-bas. On en reparlera plus tard! (Abinun 1988: 190-191).

Riki Salom (nacida en Sarajevo) hacia finales de los años 20 del siglo pasado, dice:

Car, même si nous portons toujours nos origines, nous appartenons quand même un peu a l'endroit où nous nous trouvons. Prenons mon exem- 
ple: si j'appartiens à une ville, c'est à Belgrade, si j'appartiens à une région, c'est à la Bosnie, et si j'ai une langue maternelle, c'est le ladino [...]. Ça ne me tourmente pas, mais je veux savoir où je suis, et ce n'est pas facile à établir, car je me trouve un peu partout (Gord 2000: 165).

El caso de la familia Graziani es también paradigmático. Originarios de Estambul, no hablaban turco ni los niños, ni la madre, ni la abuela. Sí los hombres, que se desempeñaban en todas las lenguas de la zona. No es extraño, ellos eran súbditos judíos del Imperio. No eran turcos, sino judíos, judíos sefardíes (Graziani-Levy 1991: 8-9). Era un clan unido por la nacionalidad (sefardí) y por las creencias (judaísmo):

We were Sephardic Jews who spoke Ladino, and the memory of Spain was still alive among us (Graziani-Levy 1991: 12).

Más tarde, Robert Graziani-Levy no sentiría contradicción entre ser judío y ser francés. Por eso desarrolló una especie de actitud negativa contra su padre por quitarle toda esperanza, por destruirle la imagen que tenía de Francia, país de futuro que sería un ejemplo para el mundo entero (Graziani-Levy 1991: 37). Pero Robert anuncia en el transcurso de una cena que va a ir a la guerra a España porque él es «Sephardic Jew and a Spanish citizen». Sigue una batalla campal. Madre y abuela se acusan mutuamente. El padre respeta la idea pero no la comparte: no dará su consentimiento porque el chico es menor de edad y sufre de asma. Sin embargo, su orden de prioridades difiere algo: Primero eran franceses, después españoles, después judíos sefardíes (Graziani-Levy 1991: 45 y 53).

También Mangeclous, el pintoresco personaje creado por Albert Cohen, dice en los aledaños de la Segunda Guerra Mundial:

Comme je suis heureux de me trouver en votre Genève, cette Genève qui est ma troisième ou quatrième patrie et dont j'estime tant les citoyens à cause de leurs instincts bienfaisants! (Cohen 2007b: 756).

Más recientemente, los últimos testimonios, los de los nacidos y criados en la diáspora, conforman un variopinto cuadro que asume su pluri-identidad con total naturalidad y proclama: ¡Somos todo a un tiempo!

Brenda Serotte (Nueva York, 1947) se pregunta de niña si realmente ellos son judíos, turcos o españoles y por qué, si son judíos, no son «realmente judíos» como sus vecinos húngaros, polacos y rusos. Se inicia entonces un simpático diálogo sobre su origen, que acaba por cuajar en la mente infantil: 
—So, we're really Spanish, and we're going back to Spain one day?

—Of course not.

-But you said.

- I did not!

My aunts were no help.

—Are we Spanish, Tante?

$-\mathrm{Si}$ !

—And Jewish, too?

$-\mathrm{Si}$ !

—But not really Turkish, right?

—Si! Of course we're Turkish! Shut up already, crazy girl! (Serotte 2006: 9).

En el mismo sentido, Rosa Nissán (Ciudad de México, 1939):

¡Ya! Acaba de entender que no tienes que escoger entre ser judío o mexicano. Está bien querer a los dos países (Nissán 1996: 106).

Y hasta hoy. En los últimos meses, por ejemplo, se han publicado en la comunidad virtual Ladinokomunita bastantes testimonios acerca del tema. Uno de los más recientes es el siguiente:

No me akodro ande lo meldi ke uno de los muestros eskrivyo dizyendo: «so judio ma me konsiento en mi alma turko en primero... i judio de religion». Ma komo yo bivi en Turkiya 1/3 i 2/3 aki en los Estados Unidos, dayinda no puedo dizir «so Amerikana kon religion judia», ni puedo mas dizir «turka» (porke solo tuve la nasyonalidad turka por 14 anyos (17 anyos italiana), ma bivi ayi por 30 anyos. Esto me izo akodrar ke enpasadas estuve en una klasa ke se yamava «idendita kon dos korasones». Era por Israel: «eske tenemos la mitad del korason por Israel i la otra por Estados Unidos?». Kuando vino la sira miya dishe: «mi korason esta no solo en dos ma en tres... porke tengo un atadisho kon la Turkiya».

Es ke me esto yerrando? Vozotros ke dizish? (Rosina desde Florida, el 24 de noviembre de 2008).

A lo que responde el mismo día Rita desde Barcelona: 
Shalom Rosina: Penso ke no te estas yerrando, de ke el lugar ande uno nase (mezmo ke penso ke tu vinites muy chika a Istanbul) i morates durante 30 anyos ayi, no puede salir fasilmente de tu korason afilu si estas el dupio en otro lugar, ansi ke me parece muy djusto ke partajates en 3 .

En esa trayectoria, y en esa asunción de la pluri o multi-identidad, es esperable que las nuevas generaciones asuman la riqueza de esta diversidad sin los traumas que hubieron de superar las anteriores generaciones.

\section{LAS «OTRAS PATRIAS»}

Advertimos al principio que en la búsqueda de la identidad sefardí cobra relieve en unos autores el rastreo de las propias raíces hasta dar con el ancestro peninsular o el lugar de procedencia de la familia; para otros, en cambio, se enraíza en extremos como las creencias religiosas, la lengua, la mentalidad o la educación, e incluso la alimentación.

Para Moïse Abinun (Sarajevo, 1912) su rasgo identitario más significativo es la fe:

Nos ancêtres se sont installés ici et là [...]. Certains étaient très pauvres, ils avaient tot perdu..., tout, sauf la foi (Abinun 1988: 99).

Esa fe tuvo una continuidad práctica en tanto las comunidades orientales gravitaban sobre sí mismas. Casi nadie osaba transgredirlas porque suponía romper con el grupo protector. En la emigración, comienza a plantearse su validez por comparación o contacto con otras prácticas religiosas. Así se manifiesta en la novela de Nizri (Ciudad de México, 1954):

Rebequita tiene razón. Salir con un muchacho cristiano amerita pena de muerte. Los padres se rasgan las vestiduras en señal de luto, pronuncian las palabras de: Adonái mos la dio, Adonái mos la kitó y una deja de ser hija de sus padres, y hermana de sus hermanos y amiga de sus amigas. Y una es expulsada definitivamente del supuesto paraíso familiar y, ante los ojos de ellos, una está muerta (Nizri 2000: 56).

Con todo, la segunda generación permanece fiel a su «religión» en la diáspora, pero sin estridencias. Así dice el suegro de Bohor León en la primera mitad del siglo XX:

Le peuple juif est un grand peuple et la religion de nos pères n'est peut-être pas la meilleure, mais je soutiens que c'est la vrai (Lagardet 2007: 367). 
Y es que, como bien explica Moïse Rahmani (El Cairo, 1944):

Paraîtrait-il complètement assimilé, transformé, converti, au fond il est absolument lui-même [...]. Que deux Juifs, pas plus que deux, se rencontrent sur un point du globe, ils fraterniseront et, surtout, ils prieront ensemble, les jours de grandes solennités rituelles, comme s'ils étaient dans une synagogue remplie de fidèles (Rahmani 2002: 36).

Las más de las veces esa identificación con la fe viene impuesta por las decisiones del poder político, ya desde antiguo, como describe muy bien Robert Sigaléa (Bucarest, 1915), porque les une excluyéndolos de otros grupos. La constitución votada con Carol I daba la nacionalidad rumana a los extranjeros de religión cristiana, pero no a los judíos. En 1878 obtuvo Rumanía su independencia. Gracias a los esfuerzos de Crémieux, la Alliance Israelïte Universelle y las potencias occidentales, los ciudadanos judíos podían pedir la nacionalización a título individual, pero no poseer tierras. A partir de 1923 se les da derecho a adquirirla de pleno derecho, pero seguirán excluidos del ejército, de los cargos públicos y de las plazas de prestigio. El diploma de bachiller de Robert llevaba la mención «De religión mosaïque» (Sigaléa 2003: 22-24). La práctica religiosa se convierte así en el asidero de cohesión comunitaria entre los sefardíes ya antes del inicio de la Segunda Diáspora.

Para otros, en cambio, cobra especial importancia en la diáspora la lengua. Isaak Behar (Berlín, 1923) — de familia oriunda de Constantinopla— así lo cree:

Diese Heimat mussten sie nun verlassen [...]. Ihre Sprache, Ladino, [...] nahmen die Vertriebenen mit (Behar 2006: 19).

De igual modo Courtine-Denamy (París, 1947) que, más pragmática, define la lengua como la auténtica patria de los sefardíes. De ahí el subtítulo de su libro (La langue pour seule patrie). Según esta autora, es lo único que les une como entidad cultural. Así, mientras lugar y tiempo les separan de los que nunca conocieron (sus antepasados que vivieron en la Península), hay «algo» que continúa a ligarles a ellos: el judeoespañol, una lengua que no tiene patria territorial, sino espiritual, inmaterial, y cuya persistencia y progresiva degradación se identifican con el grupo étnico como tal (Courtine-Denamy 2001: 54). Sin embargo, aunque de profundas raíces hispanas, los sefardíes se niegan a identificarla con el español. El judeoespañol es definido por la mayoría como una lengua «judía», no como una lengua «hispánica», como se pretende desde España.

En este sentido, he aquí el testimonio de un sefardí de hoy, afincado en Francia: 
[...] kuando muestro amigo [...] te dize ke la Espanya es muestra sigunda patria, avla por si, i no para todos. Para mi, la Espanya no es mi patria, ni sigunda ni kualkyer numero ke sea. El atado ke egzistiya entre mis antepasados i su pais fue kortado, no por eyos, ama por sus reyes, i afillu si, 500 anyos mas despues, Angel Pulido, Primo de Ribera, Franco (mas o menos) i el rey de oy trokaron la politika de la Espanya verso los djudyos, esto no puede azer de la Espanya mi patria. Lo ke fue kortado es kortado. Lo ke kedo es la lingua, ke tenemos en amor, no komo lingua espanyola, ama komo lingua djudiya, kon sus byervos tambyen turkos i ebreos, estropeados, trokados, mesklados, ke azen su espesifisidad. Por siguro, yo avlo por mi, i kada uno aki lo puede sintir de otra manera. I por siguro tambyen, lo ke dishe no tyene nada ke ver kon la amistad para los Espanyoles i los de Amerika latina. Ama amistad es una koza, patria es otra ${ }^{19}$.

Para el monastirlí Avram Sadikario (1919), lo que distingue a los sefardíes es un cierto tipo de mentalidad. Según él, los sefardíes llevaron la «mentalidad latina» a Oriente (Sadikario 2006: 5), es decir, los siglos de estancia en la Península provocaron que los judíos peninsulares que emigraron se vieran como integrados en una cultura no esencialmente judía y con rasgos propios de otras culturas.

Por fin, para Edgar Morin (París, 1921), lo que une a los sefardíes - porque así ocurrió en parte en su familia más próxima - son los usos culinarios:

Et quand le séfardisme s'est dilué chez les Francs, le noyau matriciel de sa culture a subsisté; ce noyau, comme dans toute culture, est gastronomique, et, au noyau de ce noyau, il y a le pastellico. Devenu nourriture maternelle pour ses enfants, le pastellico est désormais le seul survivant, dans le monde français et gentil de Véronique, du monde englouti de la Salonique séfarade (Morin 1989: 463).

En casi ninguna obra testimonial falta la evocación de las comidas tradicionales que todavía las madres o abuelas saben hacer y que adquieren un valor identitario por múltiples razones: porque representan la posibilidad de cumplir las prescripciones dietéticas judías, pero sobre todo por el componente de cohesión grupal que implica la reunión de la familia en torno a la mesa, y por el elemento distintivo, de afirmación de la propia identidad, que la cocina del Oriente mediterráneo adquiere en los nuevos países de asentamiento.

Es fácil observar cómo los primeros grupos de emigrados se regocijaban observando las pautas alimenticias que les mantenían ligados a su pasado. Es

\footnotetext{
${ }^{19}$ Mensaje enviado a Ladinokomunita el 9 de marzo de 2007.
} 
más, a medida que transcurría el tiempo y la distancia mental con el mundo de sus mayores se agrandaba y se difuminaban otros elementos de identidad, la alimentación — como, en parte, la lengua - fue cobrando mayor importancia hasta erigirse en emblema cultural y convertirse en el núcleo central de la vida, pues era el elemento que unía a los miembros de la familia, y la familia era vital en la diáspora ya que mantenía la cohesión entre sus miembros. En opinión de Edgar Morin (nacido Nahum), se convirtió en un factor matricial que les unía con aquel mundo perdido y añorado de sus mayores (Morin 1989: 14). Este hecho se produjo en todas las familias y en todos los lugares de la nueva emigración, de Nueva York a París, y de Berlín a Temuco, en la lejana Araucanía chilena.

Aunque el modo de vida occidental iba ya exigiendo la simplificación de los hábitos alimentarios — por los horarios comerciales, el alejamiento de la vivienda de los lugares de trabajo, y, sobre todo, la incorporación de las mujeres al mercado laboral, que hacía que dispusieran de menos tiempo para la preparación de esos festines_-, lo único que ocurrió es que se dilató la «puesta en escena» del antiguo ceremonial, pues los viernes, o con ocasión de cualquier festividad, era obligado reproducirlo, calcado de Oriente, y se consideraba una forma de cortesía asistir a él. Así, a diario se comía al modo occidental, pero los días festivos, las amas de casa seguían batallando para ofrecer a sus comensales lo mejor de la gastronomía sefardí, con las especialidades propias de origen local. Esto se mantuvo hasta que empezó a faltar la generación de las abuelas, que cocinaban las auténticas especialidades locales sin importarles el tiempo que en su confección derrochaban.

Por ejemplo, los días festivos comía Vidal Nahum en casa de su suegra, Myriam Beressi, o en casa de su hermana, Henriette Hassid (en cuya casa cocinaba también la madre de ambos, doña Helena Frances), donde se imponía la gastronomía sefardí salonicense: Raki de aperitivo, uevos de baba ahaminados, pastellico (de queso, berenjenas o espinacas), arroz con fijones, cachcaval (queso de oveja balcánico), sotlach (crema de Maizena al horno ${ }^{20}$ ), rosquitas, charopes... (Morin 1989: 167).

A veces, significativamente, las únicas palabras en judeoespañol o en las lenguas de los países de origen que aparecen escritas en los libros de memorias son, precisamente, los nombres de las distintas especialidades culinarias, como es el caso de la novela La maison de Jacob (Courtine-Denamy 2001).

El judeoespañol, lengua de origen hispánico que se convirtió en elemento identitario de los lugares de asentamiento en el Imperio otomano, se ha conver-

${ }^{20}$ Otros dicen que es arroz con leche. 
tido, con el desuso, en reliquia del tiempo pasado en los nuevos países de emigración. La mayor parte de los autores de escritos autobiográficos ya no la habla ni en familia ni en sociedad (salvo cuando se reúnen a tal efecto), si tienen algún conocimiento de la lengua es meramente pasivo y tampoco la han transmitido a sus hijos. Lo propio sucede con los usos culinarios, aunque a favor de ellos podemos decir que constituyen el único elemento de la cultura reproducible a voluntad. La lengua y los usos culinarios, en defecto de la práctica religiosa, acaban siendo una «patria» que representa a otras «patrias» (Sefarad, las comunidades tradicionales de Oriente) (Díaz-Mas - Romeu 2008).

Finalmente, en esa pluralidad de identidades tan particulares, dos broches excepcionales de la mano de Yaacov Handeli (Salónica, 1927) y del poeta de Cefalonia, Albert Cohen (Corfú, 1895).

Handeli — superviviente de Auschwitz-, después de recordarles a sus hijos que Jerusalén es la patria de todo judío, independientemente de donde haya nacido o donde viva, les dice a sus hijos que su patria es la memoria:

Moi, dont la jeunesse a tourné court et dont la ville natale a sombré dans le néant comme un continent perdu, le seul endroit où je puisse encore respirer l'atmosphère de mon enfance est ma mémoire (Handeli 2001: 15).

Y Cohen, en su novela Belle du Seigneur, después de haberle sido arrebatada brutalmente a Solal la nacionalidad francesa, reconoce como única patria a una mujer cristiana, su amada Ariane:

Il est sorti, et il a erré dans les rues, sans patrie et sans fonction, un Juif chimiquement pur [...]. Il a parlé de solitude, de sa soif de patrie, et le bonhomme lui a répondu domicile irrégulier et délai réglementaire, tout en regardant les photos de ses deux enfants bien peignées et de sa femme bien légitime, montrable et sans doute bien dotée. Oh, l'indifférence des heureux. [...] Désormais, un homme seul, et comme patrie, une femme (Cohen 2007b: 940-943).

\section{EN RESUMEN}

Los cambios históricos y las crisis económicas que se produjeron a finales de los siglos XIX y XX supusieron una revolución en el seno de las comunidades sefardíes orientales e impulsaron a sus miembros a la emigración. Así se produjo lo que se ha denominado la diáspora secundaria (o segunda diáspora) sefardí. 
Ello, junto a las trágicas consecuencias del Holocausto para los sefardíes de los países balcánicos, ha motivado que hoy en día la mayor parte de las comunidades sefardíes tradicionales hayan desaparecido de allí o estén muy disminuidas, y que la mayor parte de los judíos de origen sefardí viva en América (del Norte y del Sur), en Israel o en países europeos. Esto ha impuesto también la adaptación a nuevas formas de vida y la necesidad de construir una «nueva» identidad sefardí.

En los últimos decenios se han publicado numerosos escritos testimoniales en los que la búsqueda de esa identidad es un pilar fundamental. Aun cuando no se ha cuestionado desde España el sefardismo de los sefardíes, ni siquiera durante la campaña del Senador Ángel Pulido a principios del siglo XX, lo cierto es que de esos escritos se infiere que los sefardíes no se sienten españoles sin patria sino que España es una patria más —o matria, madrastra a veces-, ya que exhiben una pluri o multi-identidad no excluyente. Definen con nitidez que son judíos primero (su «patria» afectiva es el judaísmo), sefardíes después (su «patria» histórica es Sefarad), y, luego, depende del destino de cada cual, pueden ser franceses, turcos, italianos... (es la «patria» jurídica que les otorga la nacionalidad).

En la Primera Diáspora, mientras permanecieron en Oriente, se mantuvieron vinculados afectiva e históricamente al judaísmo (práctica de la religión) y a $S e$ farad (gloria y orgullo del pasado peninsular). En las primeras generaciones de emigrados de la Segunda Diáspora se observa un creciente apego hacia la «patria» oriental, reproducida en usos y costumbres que, como los culinarios y la lengua, refuerzan la cohesión grupal y familiar. El país donde nacieron o donde viven tampoco es necesariamente aquel del que ostentan la nacionalidad.

A medida que transcurre el tiempo, las últimas generaciones están cada vez más integradas socialmente en los países donde viven y apenas si son capaces de reproducir a voluntad aquellos elementos de la cultura propia que durante siglos formaron parte del patrimonio de su familia: la práctica religiosa disminuye para centrarse en las festividades solemnes, el conocimiento de la lengua judeoespañola se limita a una serie de proverbios o frases hechas, y sólo con esfuerzo son capaces de transmitir saberes culinarios centenarios. Pese a todo, los sefardíes de hoy siguen declarando en sus memorias ser judíos, sefardíes y orientales. Ojalá España puede convertirse en la «patria» de las nuevas generaciones de sefardíes, de «nuevos» sefardíes. 


\section{BIBLIOGRAFÍA CITADA}

Ángel Alcalá (ed.), Judíos, sefarditas, conversos. La expulsión de 1491 y sus consecuencias. Ponencias del Congreso internacional celebrado en Nueva York en noviembre de 1992 (Madrid: Ámbito, 1995).

Rosa Asenjo, «España y los sefardíes: el desastre del 98 en El Avenir», Sefarad 65 (2005), págs. 3-40 y 227-269.

Stacy Beckwith (ed.), Charting Memory: Recalling Medieval Spain (New York: Garland, 2000).

Margalit BeJARANo, «Estambul - La Habana - Miami: continuidad y transición en la herencia sefardí», en El legado de Sefarad. Los judíos sefardíes en la historia y la literatura de América Latina, España, Portugal y Alemania, comp. Norbert Rehrmann (Salamanca: Amarú Ediciones, 2003), págs. 35-48.

Esther Benbassa \& Aron Rodrigue, Historia de los judios sefardies: de Toledo a Salónica (Madrid: Abada, 2004).

Mair J. Benardete, Hispanismo de los sefardíes levantinos (Madrid: Aguilar, 1963).

Manfred BöCKER, «Antisemitismo sin judíos: España 1931-1936», en El legado de Sefarad. Los judíos sefardíes en la historia y la literatura de América Latina, España, Portugal y Alemania, comp. Norbert Rehrmann (Salamanca: Amarú Ediciones, 2003), págs. 115-139.

Paloma DíAz-Mas, Los sefardíes: Historia, lengua y cultura (Barcelona: Riopiedras, $\left.2006^{4}\right)$.

— «Corresponsales de Ángel Pulido e informantes de Menéndez Pidal: dos mundos sefardíes», en Los trigos ya van en flores. Studia in Honorem Michelle Débax, ed. Jean Alsina y Vincent Ozanam (Toulouse: Université-CNRS, 2001), págs. 103115.

— «Repercusión de la campaña de Ángel Pulido en la opinión pública de su época: la respuesta sefardí», en España en la cultura hispánica en el sureste europeo, ed. Juan González-Barba, (Atenas: MAE, 2000), págs. 326-339.

-y Pilar Romeu, «Homeland and Diaspora in Jewish Sephardic Memoirs and Autobiographical Novels», comunicación presentada al Congreso Transcending European Heritages: Liberating the Ethnological Imagination, celebrado en Londonderry (Ulster) entre el 16-20 de junio de 2008 [Inédita].

Yaël FELDMAN, «In/Différence du gender dans les fictions autobiographiques contemporaines en hébreu», Yod. Révue des Études Hébraïques et Juives 9 (2003-2004) [= La narration de soi-Autobiographies et journaux intimes], págs. 113-139.

Iacob M. Hassán, «Los sefardíes como tópico», Raíces 1 (1986), págs. 32-38. 
— «Una cultura que muere. Los sefardíes o el mantenimiento de la identidad hispana en el exilio», El País, año VI, nº 227, 26 de Marzo 1992.

— «El español sefardí (judeoespañol, ladino)», en La lengua española, hoy (Madrid: Fundación Juan March, 1995), págs. 117-140.

— «Realidad y fantasía en las relaciones recíprocas España-sefardíes», en España en la cultura hispánica en el sureste europeo (Atenas: MAE, 2000), págs. 355-369.

— (2003). «El componente hispánico de la identidad sefardí», conferencia impartida en el Coloquio Identités Sépharades et modernité (Montreal, 25-26 mayo 2003).

Henry Méchoulan, Los judios de España (Madrid: Trotta, 1993).

Elena Romero, «The Theme of Spain in the Sephardic Haskalah's Literature», en Moshé LAZAR \& Stephen Haliczer, eds. The Jews of Spain and the Expulsion of 1492 (Lancaster, California, 1997), págs. 311-327.

— «El tema de España en la literatura sefardí contemporánea», en El legado de Sefarad. Los judios sefardíes en la historia y la literatura de América Latina, España, Portugal y Alemania, comp. Norbert Rehrmann (Salamanca: Amarú Ediciones, 2003), págs. 181-200.

Pilar Romeu, Fuente clara (Salónica, 1595). Un converso sefardí a la defensa del judaísmo y a la búsqueda de su propia fe (Barcelona: Tirocinio, 2007).

— «Fuente clara. Un ejemplo de interculturalidad entre los judíos sefardíes en la segunda mitad del siglo XVI», Foro Hispánico 28: Fronteras e interculturalidad entre los sefardíes occidentales (Ámsterdam - Nueva York, 2007), págs. 45-54.

- (ed.), Moisés Almosnino. Crónica de los reyes otomanos (Barcelona: Tirocinio, 1998).

Jonathan SchORSCH, «Disappearing Origins: Sephardic Autobiography Today», Prooftexts 27 (2007), págs. 82-150.

Marie-Christine VAROL, «L'autobiographie en judéo-espagnol: la difficile affirmation du sujet entre tradition et modernité», Yod. Révue des études Hébraïques et Juives 9 (2003-2004) [La narration de soi-Autobiographies et journaux intimes], págs. 231-260.

\section{OBRAS AUTOBIOGRÁFICAS CITADAS}

Moïse AbInun, Les lumières de Sarajevo. Histoire d'une famille juive d'Europe centrale. Récit (Paris: J.C. Lattès, 1988).

Vittorio AlhadefF, Le chêne de Rhodes: Saga d'une grande famille sépharade (Paris: Éditions Paris-Mediterranée, 1998) [1 ${ }^{a}$ ed. en castellano: La cita en Buenos Aires: 
saga de una gran familia sefaradí (Buenos Aires: Nuevohacer Grupo Editor Latinoamericano, 1996), pero escrita originalmente en francés].

Leontina ArditTi, An meinem Ende steht mein Anfang: ein jüdisches Leben in Bulgarien (Viena: Milena Verlag, 2002) [1 $1^{\mathrm{a}}$ ed. en búlgaro Aufbewahrte Komboloi, Sofia: Salom 1995].

Marcos Ricardo Barnatán, El laberinto de Sión (Madrid: Anjana Ediciones, 1986) [1 $1^{\text {a }}$ ed. Madrid: Barral Editores, 1971].

Isaak BeHAR, Versprich mir, dass Du am Leben bleibst. Ein jüdisches Schiksal (Berlin: Ullstein, 2006).

Esther BenBASSA \& Aron RodRIgue, eds., Une vie judéo-espagnole à l'Est: Gabriel Arié (1863-1939), autobiographie, journal et correspondence (Paris: Éditions du Cerf, 1992).

Matilde Bensignor, De miel y milagros. Evocaciones sefardies (Buenos Aires: Milá, 2004).

Adèle-Rivka CoHen, Mon enfance sépharade: mémoires judéo-espagnoles (Paris-Montreal (Québec): L’Harmattan, 1996).

Albert CoHen, Solal ([Paris]: Gallimard, 2007a) [1ª ed. francesa, Gallimard, 1930].

— Belle du seigneur ([Paris]: Gallimard, 2007b) [1 ${ }^{\mathrm{a}} \mathrm{ed}$. francesa 1968].

Marcel CoHEn, Lettre à Antonio Saura [1930-1998] (Paris: L’Échoppe, 1997).

Sylvie Courtine-Denamy, La maison de Jacob. La langue pour seule patrie. Récit (Paris: Phébus, 2001).

Elisa Franco-Hasson, Il était une fois L'île des Roses (Beersel [Bélgica]: Clepsydre, 1996).

Ana GoRd, Parfum de pluie sur les Balkans. Roman séfarade (Lausanne: L'age d'homme, 2000) [1 ${ }^{\mathrm{a}}$ ed. Gordana Kuić, Miris kiše na Balkanu, Beograd: Vuk Karadžic, 1986].

Robert GRAZIANI-Levy, Lands of Memory. Wanderings and Wonderments of a Sephardic Jew. Edited and with a Foreword by Moshe LazAr, University of Southern California (Culver City, CA: Labyrinthos, 1991).

Erol HAKER, Once upon a time Jews lived in Kirklareli: the story of the Adato Family, 1800-1934 (Estambul: The Isis Press, 2003) [1 $1^{\mathrm{a}}$ ed. en turco: Bir Zamanlar Kırklareli' de Yahudiler Yaşardı (Istanbul: İletişim, 2002)].

Yaakov Jack Handeli, De la Tour Blanche aux portes d'Auschwitz. Un Juif grec de Salonique se souvient (Paris: L'Harmattan, 2001) [Traducido del inglés y del hebreo por Danielle Vainunska].

Stella Hasson, Du Paradis à l'enfer (Bruxelles: Clepsydre, 2007). 
Isaac KaraKo, Fleur d'ortie. Autobiographie (Paris: Biblieurope, 2001).

Lidya Kastoryano, Quand l'innocence avait un sens. Chronique d'une famille juive d'Istanbul d'entre les deux-guerres (Estambul: Les Éditions Isis, 1993).

Elli KoHEn, The Kohens del de Campavias: A Family's Sweet and Sour History in Ottoman and Republican Turkey (Estambul: The Isis Press, 2004).

Jamila-Andjela Kolonomos, Monastir sin djudios (Skopje, 2006).

Evelyne LAGARDET, Un rêve français (Paris: Flammarion, 2007).

Sam Bension Maimon, The beauty of Sephardic life: scholarly, humorous, and personal reflections; edited by Albert S. Maimon, Eugene Normand (Seattle, WA: Maimon Ideas Publications, c1993).

Samuel Mordoh, El Aba. De Salónica a Sefarad (Barcelona: Tirocinio, 2003).

Harry Moreno, Caminando y hablando. La historia real de una familia sefardí, $2^{\mathrm{a}}$ ed. (Barcelona: Dèria Narrativa, 2003).

Edgar Morin, Vidal et les siens (Paris: Éditions du Seuil [Collection Points], 1989).

Alexandre Mostrel, Une Saga Séfarade (Paris: Page après page, 2006).

Rosa Nissán, Hisho que te nazca (México: Plaza \& Janés Editores, 1996).

Vicky NizRI, Vida propia. Novela basada en la vida de Esther Schoenfeld (México: El Pirul, 2000).

Isaac PAPO, Viaje en el ocaso de una cultura ibérica: Recuerdos y reflexiones de un médico sefardí (Barcelona: Tirocinio, 2006).

Victor Perera, The Cross and the Pear Tree. A Sephardic Journey (Berkeley-Los Angeles: University of California, 1996) [1 ${ }^{a}$ ed. New York: Knopf, 1995].

Moïse Rahmani, Shalom Bwana. La saga des Juifs du Congo (Paris: Romillat, 2002).

Avram SAdiKARIo, Raizes (Skopje: A. Sadikario, 2006).

Brenda SEROTTE, The fortune teller's kiss (American Lives) (University of Nebraska Press, 2006).

Moshe Shaltiel-Gracian, Shaltiel: one family's journey through history (Chicago: Academy Chicago Publishers, 2005).

Robert Sigaléa, De Bucarest à Siaugues ou le chemin des écoliers et les sentiers de la peur (Félines [Francia]: Éditions du Fayet, 2003).

Angel Wagenstein, Abraham le poivrot (Loin de Tolède) (Paris: L'Esprit des Péninsules, 2005) [1 $1^{\mathrm{a}}$ ed. en búlgaro, 2002].

Recibido: 22/01/2009

Aceptado: 01/02/2010 